\title{
The Impact of Implementing an Enterprise Resource Planning System on Organizational Performance Using Balanced Scorecard
}

\author{
Rifat O. Shannak \\ Professor of Management Information Systems \\ MIS Dept., Faculty of Business, University of Jordan \\ E-mail: rshannak@ju.edu.jo
}

Received: Oct. 12, $2015 \quad$ Accepted: Nov. 10, $2015 \quad$ Published: January 1, 2016

doi:10.5296/jmr.v8i1.8523 URL: http://dx.doi.org/10.5296/jmr.v8i1.8523

\begin{abstract}
ALPHA Company is an exclusive shopping community in the Middle East covering 8 countries (The GCC Region, Lebanon \& Jordan) and provides exclusive access to time limited sales of different brands at discounts reaching $50-85 \%$ off retail price to its 3 million members and one million Facebook fans. The company has distinguished itself by offering an amazing collection of new brands and latest fashions at privileged prices and acceptable lead time.
\end{abstract}

This research was conducted to appraise the organizational performance before and after implementing the ERP system using the Balanced Scorecard as a performance tool measurement.

The company was facing many problems in the value chain including primary and support activities. It was suffering from inefficiencies within the internal operations (Logistics and Shipping, sourcing, procurement and warehousing), in addition to a lot of difficulties in managing its financial transactions.

Based on the results of this research, it was concluded that after implementing the ERP system, the company became more efficient and effective in the value chain activities. In addition, its performance was enhanced and most of the problems were resolved successfully which led to better customer satisfaction and better reputation in the market.

Keywords: ERP, BSC, Discount Store, e-Commerce, Organizational Performance 


\section{Introduction}

\subsection{The Company's Background}

ALPHA Company was established by a young Jordanian entrepreneur in November 2010 as an exclusive online shopping community with a unique invitation-only membership. Their members could discover private sale campaigns that offered unique brands and styles for just a brief window of time. Their focus is on the most sought-after collections from the premiere brands and boutiques in the world, selling products of different yet related categories such as clothing, accessories (i.e. Jewelry, Watches, Sunglasses, etc.), home fashion, and electronic gadgets.

The company was founded by experienced professionals at leading firms in the fashion and lifestyle products industry. These were seasoned shoppers and experienced e-commerce engineers. They joined together to bring their passion, experience and the latest offerings to the fashion lovers of the Middle East. Their personal connections made it possible for the company to offer exclusive prices for most sought-after brands. ALPHA's Web 2.0 site offered a unique touch to the shopping experience for the fashion savvy. The company has distinguished itself by offering an amazing collection of new brands, latest fashions and privileged prices.

The founder's vision along with a collaborative team effort was able to rapidly move the company from a start-up into a growing, profitable and attractive business. Due to the strong start and promising results it was able to attract a group of individual and institutional investors to raise a total capital of almost 15 million U.S dollars. Currently the company is funded by the elite Investors. Having such Capital, the company was granted a position as the fastest growing e-commerce business in the Middle East region.

With a Head Office Located in Amman-Jordan, the company is currently employing over 300 employees and operating in Jordan, Lebanon and GCC countries to offer customers exclusive offerings in a new way that is going epic and creating phenomenon all over the region. The bottom line ALPHA company is one of the most promising companies in Jordan and the region due to its visionary leadership, highly motivated team, and market attractiveness.

\subsection{Netsuite}

ALPHA Company implemented its Netsuite software in order to make better, faster decisions in a fiercely competitive market. Netsuite incorporation provides on-demand enterprise resource planning (ERP) and customer relationship management (CRM) application software. It also enables the company to bring together departments and automate processes, beginning with sales and ending with customer invoices.

\subsection{Enterprise Resource Planning System (ERP)}

It is apparent that there is a consensus on the definition of ERP. One ERP implementation can vary widely from the other. Perhaps, the differences underscore the flexibility that might render an ERP as a truly powerful business tool. 


\section{Ml Macrothink}

ERP is an acronym for Enterprise Resource Planning. It brings together all of the various processes that are essential to running a business, including inventory and order management, accounting, human resources, customer relationship management (CRM), and beyond. ERP integrates the various functions of the business into one complete system to streamline processes and information across the entire organization.

In general, an ERP is computer software that is used by the company mainly to manage and coordinate the business processes. It is expected to save time and cost, to make decisions faster and to reduce errors which should enable the company to achieve its intended goals and objectives.

The central feature of all ERP systems is a shared database that supports multiple functions used by different business units including: Product and planning development, Manufacturing, Marketing and sales, Inventory management and Shipping. In practice, this means that employees in different units - for example, accounting and sales - can rely on the same information for their specific needs. It enables the company to be effective in pursuing the e-commerce model for the business. The software tracks information, material, cash and share it across the different departments and units in the organization.

As discussed on NETSUITE site, some of the hypothesized advantages of ERP are:

1. Facilitating sales forecasting through inventory optimization.

2. Automating core business operations such as lead-to-cash, order-to-fulfillment, and procure-to-pay processes.

3. Giving a universal, real-time view of data that can enable companies to address concerns proactively and drive improvements.

4. Enhancing customer service by providing one source for billing and relationship tracking. Figure 1depicts how the ERP system is hypothesized to affect various aspects of the business:

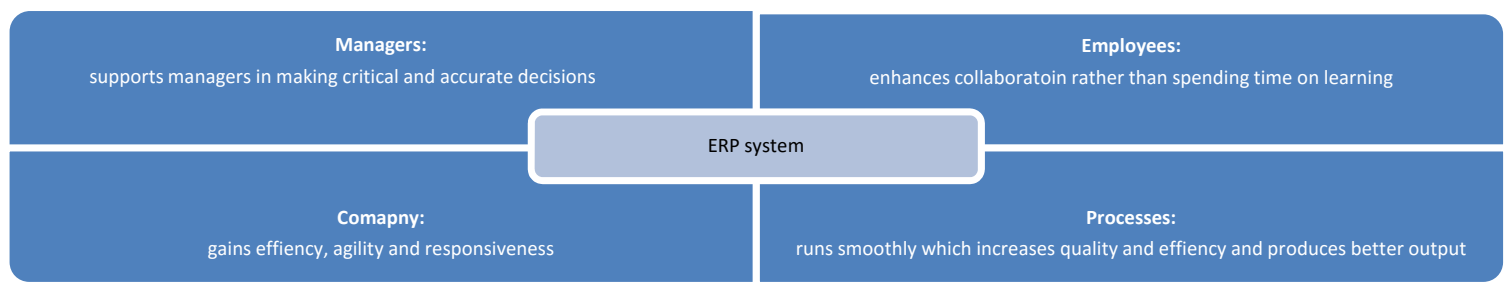

Figure 1. Some ERP hypothesized Effects on Various Aspects of the Business

\section{The Evolution of ERP:}

ERP system came to life in 1960s as material resource planning (MRP); MRP was mainly about finding a better way to order material and components by answering the following questions: 


\section{MRP}

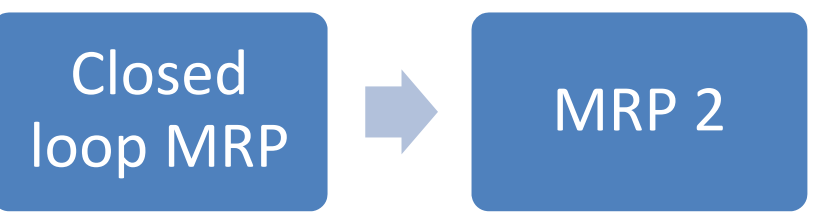

Figure 2. Evolution of ERP

1. What are we going to make? (schedule)

2. What does it take to make it? (bill)

3. What do we have? (inventory records)

4. What do we have to get? (future requirements)

It was then realized that something more than just ordering a material is needed. The closed loop MRP was proposed. It was meant to introduce the following advantages in addition to knowing what we really want to order and what we have in the inventory:

- Tools to address the capacity and priority and to support planning and execution.

- Tools that enable the flow of feedback from the execution to the planning department.

The MRP 2 was later introduced. It was able to balance demand and supply together in order to translate the operating plan (in pieces, gallons, etc.)into financial terms, and was able to ask "what if" questions.

The implementation of ERP system largely depends on what is called the "ABC approach", which consists of three different items with various levels of significance:

- Item "A", which is of high level of significance in ERP, consisting of the people who will run the job and keeping track of the all the transactions.

- Item "B", which is of moderate level of significance, consisting of data needed; inventory records, bills of material...etc.

- Item "C", which is the lowest level of significance, consisting of the computer (hardware and software). It is important since the ERP cannot work manually and it is meaningless without the flow of information inside it as well as people to make things done.

\subsection{Balanced Scorecard (BSC)}

BSC is a measurement tool framework that is built to articulate strategy into actionable terms. It focuses on measuring many aspects including financial and non-financial terms.

BSC takes into consideration that the ultimate goal is to enhance the financial outcome, but focuses along the way on customers, learning and growth, and business processes.

The four dimensions of the BSC are (Figure3): 


\section{Macrothink}

1. Learning and growth: learning includes training, mentoring and tutoring within the organization, ease of communication to resolve problems, where as growth includes employee turnover and gender ratio.

2. Business processes: how well the processes are running, whether the product/service is under the customer specifications, also it includes the number of orders, execution time and number of errors and defects.

3. Customers: customer's satisfaction which will lead to customer retention which will also lead to customer loyalty.

4. Financial: return on equity (ROE), return on investment (ROI), cash flow... etc.

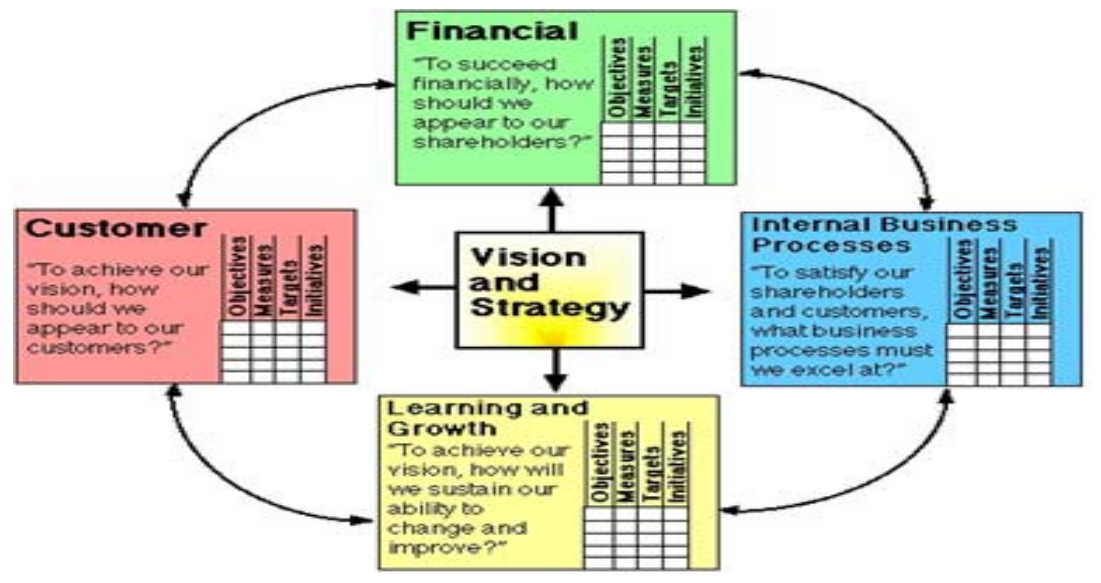

Figure 3. Dimensions of BSC (Kaplan, 2010)

\section{The Research}

\subsection{Title of the Research}

The research paper is entitled "The Impact of Implementing the Enterprise Resource Planning (ERP) System on the company's performance using the Balanced Scorecard" as a performance measurement tool. The focus is therefore on investigating if the ERP implementation has an impact on the performance of ALPHA using the Balance Scorecard measurement tool.

\subsection{Objectives of the Research}

The objective of the study was to evaluate the company's performance before and after implementing the ERP using the BSC as a performance measurement tool.

The following diagram depicts a framework (Laudon and Laudon, 2014) describing the proposed relationship between the technology, organization and management. It shows howthe ERP as an information systemwould create value for ALPHA as possible organizational and management solutions to challenges posed by the environment. 


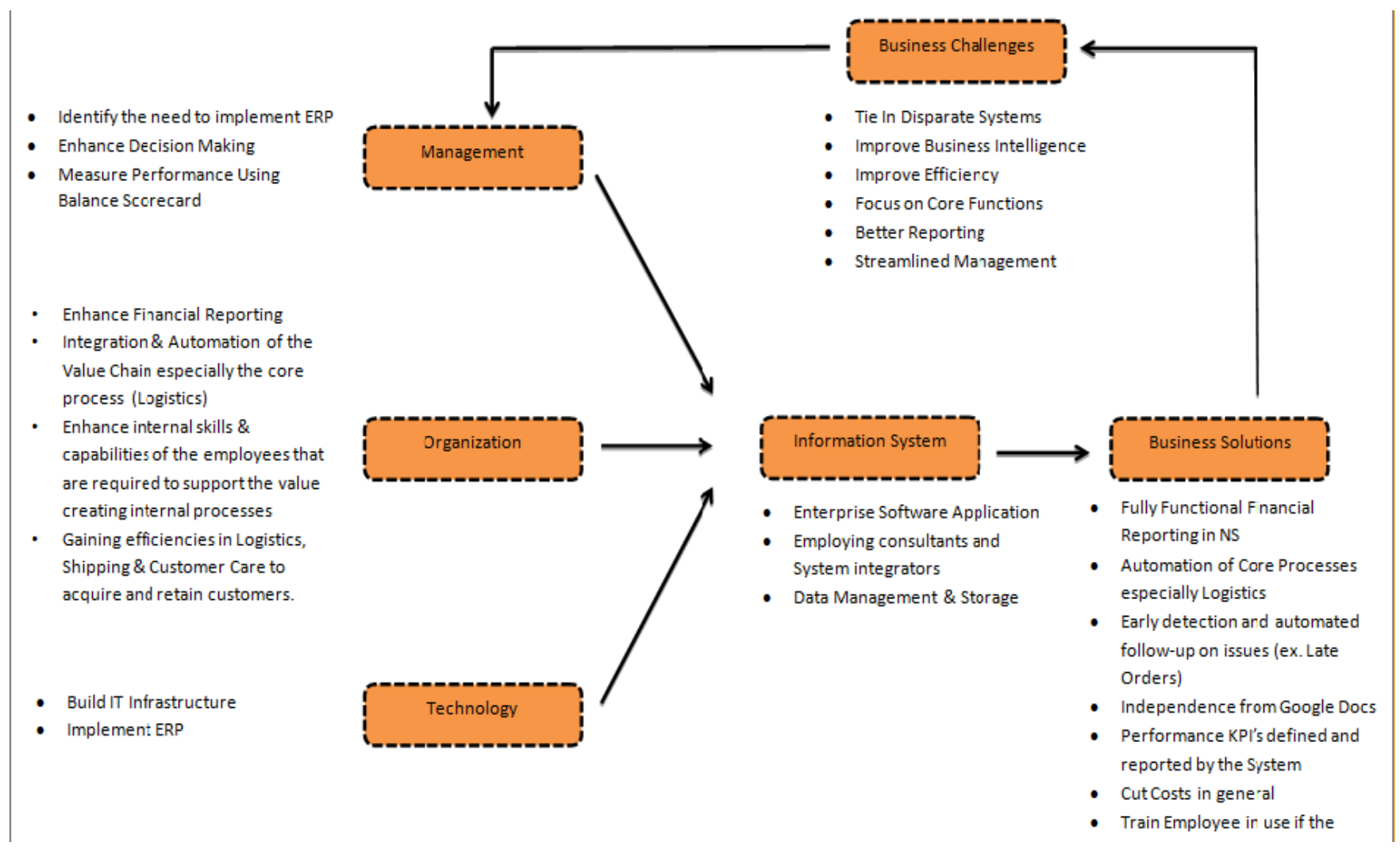

Figure 4. A Framework Analysis for Advantages of Using ERP in ALPHA

\subsection{The BSC and the ERP}

Norton and Kaplan (1992) introduced the Balanced Scorecard in a 1992 Harvard Business Review article. The article was based on a multi-company research project to study performance measurement in companies whose intangible assets played a central role in value creation (Nolan Norton Institute). Norton and Kaplan believed that if companies were to improve the management of their intangible assets, they had to integrate the measurement of intangible assets into their management systems. Kaplan stated that when you can measure what you are speaking about, and express it in numbers, you know something about it; but when you cannot measure it, when you cannot express it in numbers, your knowledge is of a meager and unsatisfactory kind. If you cannot measure it, you cannot improve it. (Kaplan, 2010)

Collectively, the ERP can be considered as an enterprise-wide set of management tools that balances demand and supply, containing the ability to link customers and suppliers into a complete supply chain, employing proven business processes for decision-making, and providing high degrees of cross-functional integration among sales, marketing, manufacturing, operations, logistics, purchasing, finance, new product development, and human resources, thereby enabling people to run their business with high levels of customer service and productivity, and simultaneously lower costs and inventories; and providing the foundation for effective e-commerce. Here are some descriptions of ERP, not definitions but certainly good examples. Enterprise Resource Planning might mean that a company could 
increase its sales by 20 percent in the face of an overall industry decline.

Enterprise Resource Planning is a purchasing department generating enormous cost reductions while at the same time increasing its ability to truly partner with its suppliers. The director of purchasing claimed: "For the first time ever, we have a good handle on our future requirements for components raw and materials. When our customer demand changes, we-ourselves and our suppliers - can manage changes to our schedules on a very coordinated and controlled basis. I don't see how any company can do effective supply chain management without ERP.'That's ERP. Here's how it came to be. (Wallace and Kerman, 2011).

An ERP system can be defined as an adaptable and evaluative commercial package that supports, in real time and in integrated manner, the management of most if not all of a firm's business processes. One can attempt o better define it by looking at its characteristics. In this regard, an attentive observer of both the research and professional literature will denote quite a number of attributes deemed to be possessed by ERP systems. Characteristics generally attributed to ERP systems in the literature are presented in Table 1. In doing so, an attempt has been made to include all characteristics, notwithstanding the different terminologies used by different authors in describing them. (Sylvestre and Raymond, 2013)

In spite of the announced benefits of ERP, its implementation is a costly and complex undertaking (Markus et al., 2000; Griffith et al., 1999) with many firms failing to realize the expected benefits. Some companies lost not only invested capital in ERP package, but also a major part of their businesses. Much of the literature reports the unsuccessful implementations of ERP, with many organizations suffering fatal results or even deciding to abandon the whole implementation of the projects (Bhatti, 2005). Martin (1998) explained that as high as $90 \%$ of ERP implementations turn into runaway projects, are late or over budgeted. Nevertheless, it has also been reported in the literature that the success rate of ERP was as low as $10 \%$ in some countries (Zhu and Ma, 1999).

The management of Enterprise Resource Planning (ERP) Software includes two main tasks, the implementation and the use of this comprehensive software. The Balanced Scorecard, a framework originally developed in order to structure the performance measurement of an enterprise or a department can be used for the evaluation of these tasks. Adapting the approach of the Balanced Scorecard and adding a new fifth project perspective increases the completeness and the quality of ERP implementation reports. At least it raises the awareness for relevant factors. Controlling the ERP usage can be based on a "classical" BSC (top down) and utilize the aggregation of ERP monitoring data (bottom up).

In order to have the ERP system working not just effectively, but also efficiently, the gathering, processing, and formatting of information should be computerized as much as possible. Traditionally the process of controlling an investment like an ERP system ends with the delivery of the system to the users. Approaches that are related to the productive phase of the ERP system focuses mainly on the financial effects in terms of costs. Based on the Balanced Scorecard we also want to develop a set of interrelated measures that give a more complete insight into the performance of the ERP system beyond financial key performance 
indicators.

The implementation of ERP software is not a typical domain for the Balanced Scorecard approach because only one process - the implementation process - is evaluated. Nevertheless, it seems worthwhile to adapt the perspectives within the Balanced Scorecard for this purpose.

Two reasons motivate the use of the Balance Scorecard for controlling and evaluating an ERP implementation namely:

First, the Balanced Scorecard highlights the four perspectives discussed above. In addition to the four "classical "perspectives (financial/cost, customer, internal processes, and innovation and learning), it is recommended to add at least for ERP implementation, but not for ERP usage (see section 3), a fifth perspective - the project perspective. Balanced Scorecards are typically designed to monitor business processes. Using the Balanced Scorecard for a project like the introduction of ERP software is slightly different from this purpose as it focuses in most cases on only one process -implementation. The individual project requirements (identification of the critical path, definition of milestones, evaluating the efficiency of the project organization) are covered by this perspective which represents all the project management tasks.

Second, one main objective of the Balanced Scorecard is the consistent transformation of visions into strategies, objectives and measures. The implementation of ERP software can be interpreted as an example of this general objective. Visions describe the general motivation for the selection of ERP software (e. g. use of only one integrated information system). Strategies like the selection of the relevant ERP modules, the design of the project plan, or the project organization represent the framework for the definition of objectives. The main objective of the implementation process is an economically efficient customization of the ERP software that follows strategic goals and conforms to these objectives. As a consequence, the use of the Balanced Scorecard within an ERP project leads to a documentation of the expected benefits of the ERP system, which is otherwise not necessarily existing. The Balanced Scorecard is an addition to available ERP-specific implementation tools (Brand, 1999) of high importance as it serves as a guideline for the evaluation of the entire ERP project. By contrast, current implementation tools mainly focus on the project perspective and the step-by-step completion of all relevant configuration tasks. (Rosemann and Jens, 2013)

\section{Methodology}

This research was carried out using a scientific approach. The main goal was to evaluate the company's performance (dependent variable) before and after implementing the ERP (independent variable) using the BSC as a performance measurement tool. The data was gathered over a month period. An interview was held with the strategic director to get an overview about the company's past performance in order to compare the outcomes of the BSC after implementing the ERP. A questionnaire was distributed to the clients (target segment)and data was analyzed accordingly.

The research employed two techniques for data collection: 
1- Secondary data collection: This was obtained from the literature review highlighting the important variables related to the research. Several mediating variables were obtained such as culture, structure, processes, management decision and competitive environment. Whereas the moderating variables comprised of training programs for employees and managers, supportive management, team spirit and youth.

2- Primary data collection: This data was obtained from the interview with the management and the questionnaire that was administered to a sample of ALPHA's clients.

The final results were analyzed both qualitatively from the managers' perspectives and quantitatively through the use of a statistical program thereby using tables, charts, and graphs to analyze and interpret the data. The conclusion and recommendations were then presented as a result.

\subsection{Research Model}

The figure below depicts the research model that was used for guiding the study of the case, highlighting the independent, moderating, mediating and dependent variables.

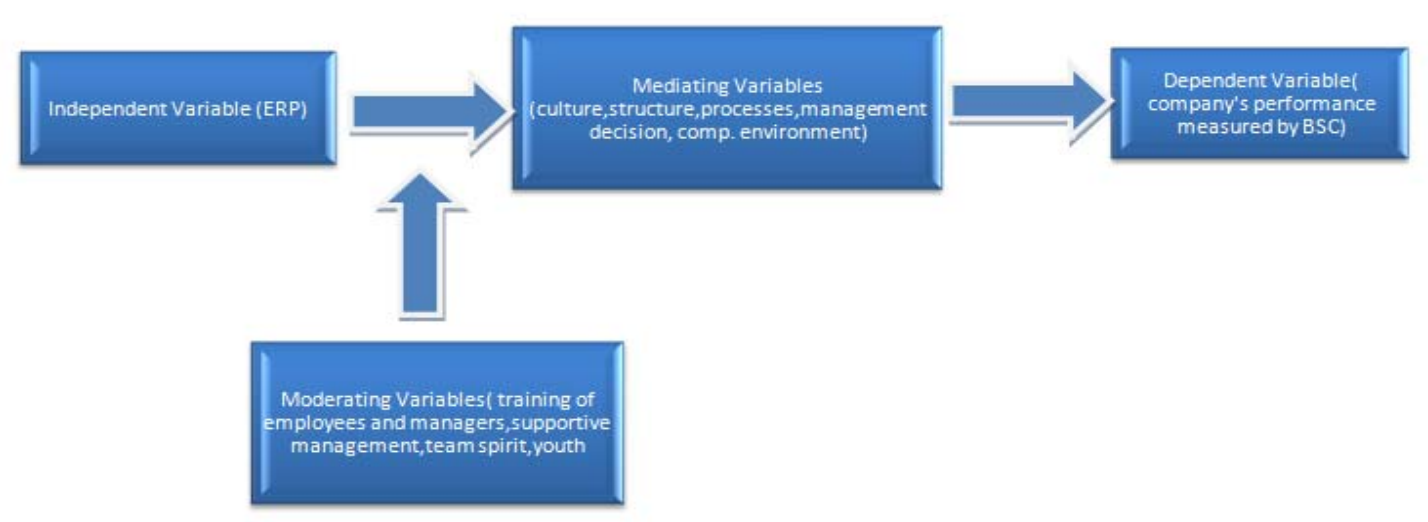

Figure 5. Research Model

This following figure depicts the balanced scorecard methodology that many managers use to measure the performance of their business, and to understand how firm strategies are impacting the four dimensions of interest. For each of these dimensions, performance is operationalized by identifying the most important key performance indicators (KPI) for eachdimension. 


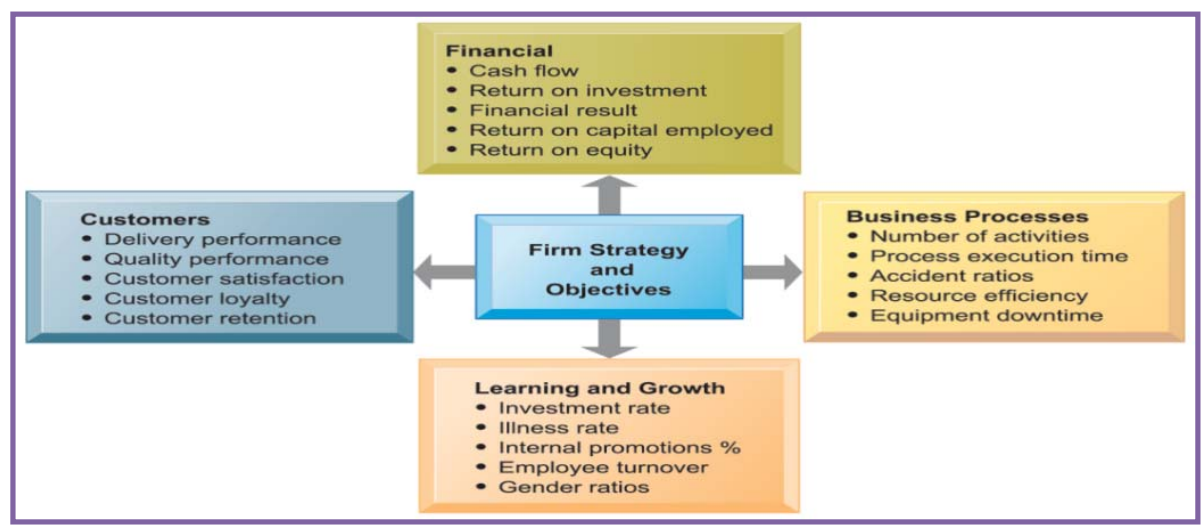

Figure 6. The Balanced Scorecard Framework

The following table represents the characteristics of ERP and the operationalizationusing a definition or an explanation of the construct.

Table 1. ERP Characteristics

\begin{tabular}{|c|c|}
\hline Characterstics & Explanatory elements \\
\hline Integration & $\begin{array}{l}\text { Interaction between functions and } \\
\text { hierarchicallevels } \\
\text { Interaction between the various } \\
\text { processes }\end{array}$ \\
\hline Completeness (generic function) & $\begin{array}{l}\text { Wide range of functions } \\
\text { Applicable to various types of firms } \\
\text { Connectivity with the outside }\end{array}$ \\
\hline Homogenisation & $\begin{array}{l}\text { Unique data refer ential } \\
\text { uniformoity of human-machine } \\
\text { interface } \\
\text { unicity of the system's } \\
\text { administration }\end{array}$ \\
\hline Real-time & Real-time upd ate and consultion \\
\hline Ad ap tability (flexibilty) & $\begin{array}{l}\text { Capability to follow rule and } \\
\text { organization changes (made possible } \\
\text { by parametring) }\end{array}$ \\
\hline Opennes (evolutionary) & $\begin{array}{l}\text { Modularity } \\
\text { Portability }\end{array}$ \\
\hline Transw ersality (process-oriented view) & $\begin{array}{l}\text { System designed in regard to the } \\
\text { business processes } \\
\text { Necessary to achieve objectives } \\
\text { Focus on value rather than } \\
\text { authority flows }\end{array}$ \\
\hline Best practic es & $\begin{array}{l}\text { System imbeds best practices in the } \\
\text { field }\end{array}$ \\
\hline Simulation & Business processes can be simulated \\
\hline
\end{tabular}




\section{Macrothink}

\section{Results and Analysis}

\subsection{Introduction}

This section presents and discusses the research results obtained from the analysis of the data. The table below represents the company's situation before and after implementing the system.

Table 2. Company's Situation Before and After Implementing the ERP

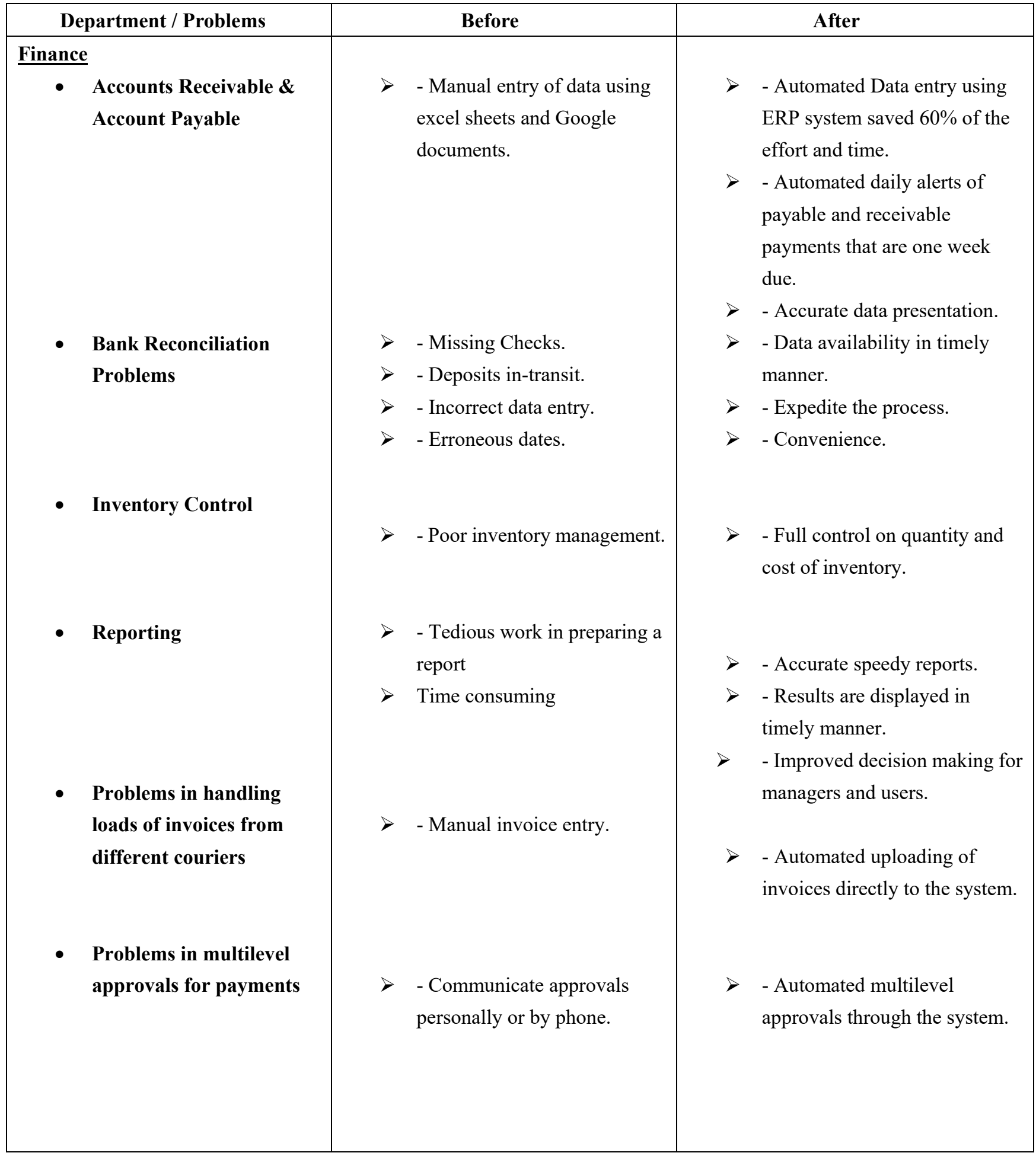




\section{Macrothink}

Table 2 .... continued

\begin{tabular}{|c|c|c|c|c|}
\hline Supply Chain & & & & \\
\hline $\begin{array}{l}\text { Sourcing \& Procurement: } \\
\text { - Agreements with } \\
\text { vendors }\end{array}$ & $>$ & $\begin{array}{l}\text { - Lack of information sharing } \\
\text { and availability between } \\
\text { different departments } \\
\text { (Sourcing, Procurement \& } \\
\text { Finance) }\end{array}$ & $>$ & $\begin{array}{l}\text { - Information flow freely across } \\
\text { different departments and can } \\
\text { be shared or accessed in a timely } \\
\text { manner. }\end{array}$ \\
\hline $\begin{array}{l}\text { - Vendors' evaluation \& } \\
\text { Selection }\end{array}$ & $>$ & $\begin{array}{l}\text { - No vendors' evaluation was } \\
\text { done. }\end{array}$ & $>$ & $\begin{array}{l}\text { - The system enables the } \\
\text { company to evaluate and select } \\
\text { the suppliers based on different } \\
\text { criteria (Quality, lead time, } \\
\text { communication \&cost) }\end{array}$ \\
\hline $\begin{array}{ll}- & \\
\text { generation }\end{array}$ & $>$ & $\begin{array}{l}\text { - Purchase orders were done } \\
\text { manually } \\
\text { Effort and time consuming }\end{array}$ & $>$ & $\begin{array}{l}\text { - Purchase Orders are generated } \\
\text { through the system. } \\
\text { - Increased efficiency in PO } \\
\text { generation }\end{array}$ \\
\hline $\begin{array}{l}\text { - Supplier Information } \\
\text { availability }\end{array}$ & $>$ & - Duplications and redundancy & $>$ & - Centralized supplier info \\
\hline $\begin{array}{l}\text { - Control of events } \\
\text { (Products) }\end{array}$ & $>$ & $\begin{array}{l}\text { - Some delayed events were } \\
\text { missed }\end{array}$ & $>$ & $\begin{array}{l}\text { - The system sends notifications } \\
\text { and alerts regarding delayed }\end{array}$ \\
\hline - Forecasting & $>$ & $\begin{array}{l}\text { - Inability to forecast or predict } \\
\text { future sales volume }\end{array}$ & $>$ & $\begin{array}{l}\text { events } \\
\text { - Almost accurate forecasting } \\
\text { for future sales volume }\end{array}$ \\
\hline $\begin{array}{ll}\text { Warehousing } & \text { (Receiving } \\
\end{array}$ & & & & \\
\hline Fulfillment, Inventory) & & & & \\
\hline $\begin{array}{ll}\text { - } & \text { Tracking of products } \\
\text { (Item level \& order level) } \\
\text { throughout the } \\
\text { warehouse }\end{array}$ & $>$ & $\begin{array}{l}\text { - Difficulty in identifying } \\
\text { product location } \\
\text { - All logistics information } \\
\text { were manually entered }\end{array}$ & $>$ & $\begin{array}{l}\text { - Ability to track the products } \\
\text { throughout the warehouse } \\
\text { - Ability to identify the bottle } \\
\text { necks during the process } \\
\text { - Accurate reporting. }\end{array}$ \\
\hline Logistics \& Shipping & & & & \\
\hline $\begin{array}{ll}\text { - } & \text { Outbound Logistics } \\
\text { - } & \text { Internal \& external } \\
\text { Tracking of the } \\
\text { dispatched product }\end{array}$ & $>$ & $\begin{array}{l}\text { - Difficulty in tracking the } \\
\text { shipment }\end{array}$ & $>$ & $\begin{array}{l}\text { - Automated shipment } \\
\text { scheduling \& monitoring } \\
\text { - Accurate tracking of the } \\
\text { shipment } \\
\text { - Accurate Reporting }\end{array}$ \\
\hline
\end{tabular}




\section{Mll Macrothink}

The above table detailed the primary activities present in the value chain (the financials and the internal business operations) and how the implemented information systems enabled the company to leverage its financial and nonfinancial performance.

As for the human resource management which is considered a support activity, the company uses the MenaME which is part of the MENAITECH human resource management system. MENAITECH is an online software that is specialized in the development of human capital information system (HCIS). It helps the organization to implement the best practices in HR function which includes recruitment and selection, training and development, appraisal, succession planning and others that contributes to the learning and development inside the organization. The MenaME is a web-based self service system for both the employees and the managers. It enables them to edit and view the HR related information online. This way the employees get involved in their individual HR function and take responsibility for data entry and accuracy of their personal information, hence reducing the amount of calls and paperwork performed by HR professionals, therefore enhancing efficiency and convenience.

\subsection{Customers' Survey Results and Analysis}

A survey was distributed to 50 external clients who already purchased from ALPHA in order to analyze the overall satisfaction level by monitoring specific features.57\% of the respondents were active buyers, $51 \%$ of the respondents have (LTVs: life time value) between $\$ 500-\$ 3000$.

The following tables and figures allow us to easily interpret the results of the questionnaire:

Question "1": What do you like most about ALPHA Company? (Multiple selections are possible)

Table 3. Results of Question 1

\begin{tabular}{|l|c|c|}
\hline \multicolumn{1}{|c|}{ Factor } & Before & After \\
\hline Fantastic deal & $\mathbf{5 2 \%}$ & $\mathbf{5 8 \%}$ \\
\hline Quality of products & $\mathbf{4 8 \%}$ & $\mathbf{5 3 \%}$ \\
\hline Price & $\mathbf{5 1 \%}$ & $\mathbf{5 8 \%}$ \\
\hline $\begin{array}{l}\text { Reliable and friendly cus } \\
\text { service }\end{array}$ & $\mathbf{4 5 \%}$ & $\mathbf{5 4 \%}$ \\
\hline Door step delivery & $\mathbf{6 0 \%}$ & $\mathbf{7 1 \%}$ \\
\hline Return policy & $\mathbf{1 0 \%}$ & $\mathbf{2 7 \%}$ \\
\hline Others & $\mathbf{6 \%}$ & $\mathbf{7 \%}$ \\
\hline
\end{tabular}

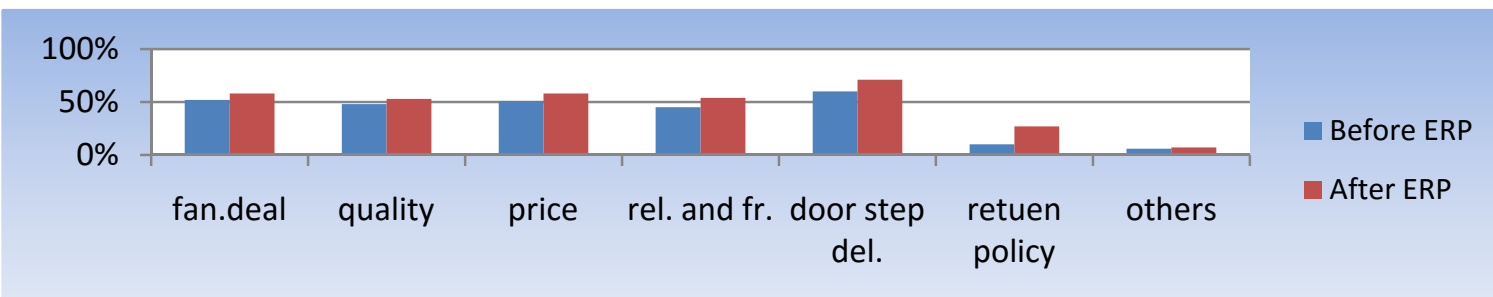

Figure 7. Bar-Chart Representation (Question 1) 


\section{Macrothink}

Question "2": Is our customer service team... (Multiple selections are possible)

Table 4. Results of Question 2

\begin{tabular}{|l|c|c|}
\hline \multicolumn{1}{|c|}{ Factor } & Before & After \\
\hline Quickly identify issue & $\mathbf{2 8 \%}$ & $42 \%$ \\
\hline $\begin{array}{l}\text { Appear knowledgeable } \\
\text { competent }\end{array}$ & $\mathbf{2 5 \%}$ & $\mathbf{3 8 \%}$ \\
\hline $\begin{array}{l}\text { Help you understand the } \\
\text { and the sol. }\end{array}$ & $\mathbf{3 0 \%}$ & $\mathbf{4 8 \%}$ \\
\hline $\begin{array}{l}\text { Handle issues with courtes } \\
\text { professionalism }\end{array}$ & $\mathbf{5 5 \%}$ & $\mathbf{6 0 \%}$ \\
\hline
\end{tabular}

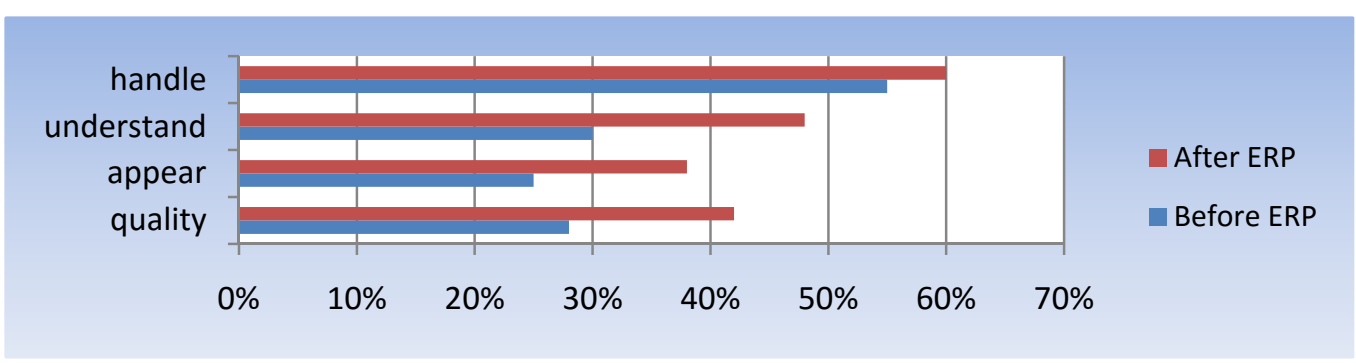

Figure 8. Bar-ChartRepresentation (Question 2)

Question “3”: How satisfied are you with the following characteristics of our products?

Table 5. Results of Question 3

\begin{tabular}{|l|c|c|}
\hline \multicolumn{1}{|c|}{ Factor } & Before & After \\
\hline Quality of the product & $\mathbf{5 5 \%}$ & $\mathbf{8 8 \%}$ \\
\hline Price of the product & $\mathbf{4 8 \%}$ & $\mathbf{6 8 \%}$ \\
\hline Item description & $\mathbf{5 2 \%}$ & $\mathbf{7 6 \%}$ \\
\hline Website user friendliness & $\mathbf{6 9 \%}$ & $\mathbf{9 3 \%}$ \\
\hline Delivery time & $\mathbf{2 5 \%}$ & $\mathbf{4 4 \%}$ \\
\hline After sale service & $\mathbf{3 5 \%}$ & $\mathbf{5 9 \%}$ \\
\hline
\end{tabular}

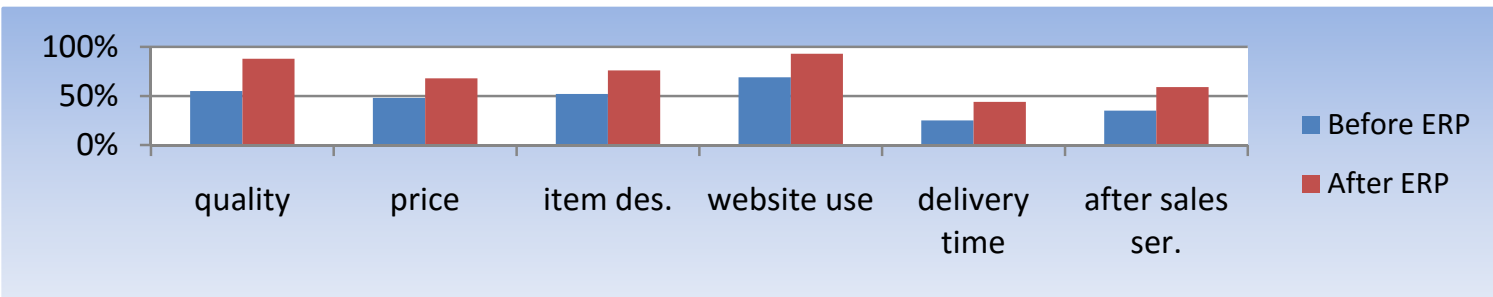

Figure 9. Bar-chart Representation (Question 3)

Question "4": In case you encountered an issue with an order or product, how long did it take to attend to and solve your issue or query? 


\section{Macrothink}

Table 6. Results of Question 4

\begin{tabular}{|l|c|c|}
\hline \multicolumn{1}{|c|}{ Factor } & Before & After \\
\hline Within 24 hrs & $45 \%$ & $\mathbf{6 6 \%}$ \\
\hline After 24 hrs & $15 \%$ & $\mathbf{2 6 \%}$ \\
\hline Still unresolved & $40 \%$ & $\mathbf{8 \%}$ \\
\hline Total & $\mathbf{1 0 0 \%}$ & $\mathbf{1 0 0 \%}$ \\
\hline
\end{tabular}

\section{Before ERP}

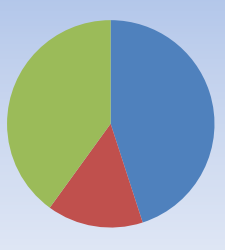

\section{within $24 \mathrm{hrs}$ \\ after $24 \mathrm{hrs}$ \\ still unresolved}

Figure 10. Pie-Chart Representation (Question 4)

\section{After ERP}

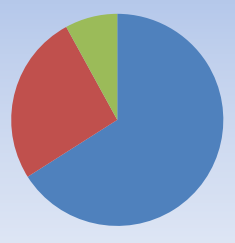

$$
\begin{aligned}
& \text { within } 24 \mathrm{hrs} \\
& \text { after } 24 \mathrm{hrs} \\
& \text { still unserolved }
\end{aligned}
$$

Figure 11. Pie-Chart Representation (Question 4)

\section{Question "6": Would you recommend ALPHA Company to your friends?}

Table 7. Results of Question 6

\begin{tabular}{|l|l|l|}
\hline \multicolumn{1}{|c|}{ Answer } & \multicolumn{1}{|c|}{ Before } & \multicolumn{1}{c|}{ After } \\
\hline Yes & $72 \%$ & $98 \%$ \\
\hline No & $28 \%$ & $2 \%$ \\
\hline
\end{tabular}

\section{Before ERP}
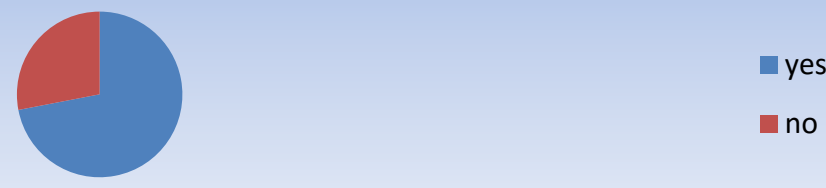

Figure 12. Pie-Chart Representation (Question 6) 


\section{After ERP}
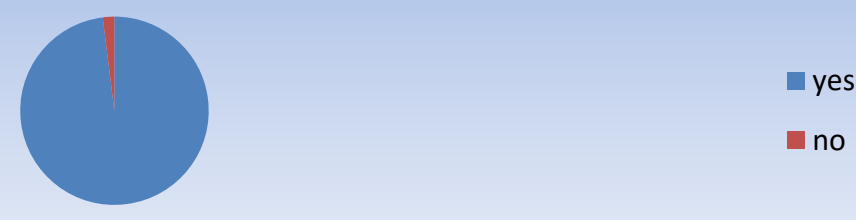

no

Figure 13. Pie-Chart Representation (Question 6)

We notice from the above questions and the results mentioned in the tables, ERP system had significantly improved the overall performance of the company in many aspects mentioned in the distributed questionnaire.

The satisfaction levels percentage have noticeably increased by monitoring different factors like: quality of the product, item description, delivery time and after sale services.

Customers were also asked to evaluate the time it takes the company to resolve their problem, as we can see in table 6 before implementing the ERP system $45 \%$ of the respondents said that it takes less than $24 \mathrm{hrs}$, while after implementing the system $66 \%$ of the respondents said so.

Regarding the customer service team, the percentages on different characteristics that described the efficiency of the team had also improved significantly. Before applying the system $72 \%$ of the respondents will recommend it to others while $98 \%$ of the respondents will recommend it after applying it.

\section{Conclusions and Recommendations}

In fact implementing the ERP and the CRM systems enhanced the company's performance which enabled the company to respond to the dynamic environment and gain a strategic position in the market. This was reflected on the balanced scorecard with its four dimensions (financial, customer, internal business processes, learning and growth) as mentioned earlier, thus enabling the company to achieve its strategic and financial goals and sustain a competitive advantage as offering an amazing collection of new brands and latest fashions at privileged prices and acceptable lead time among its rivals.

- We recommend that the company should consider decreasing its lead time by evaluating their potential suppliers and ranking them according to weighted criteria such as price, service quality, on time delivery.

- Also maintaining a certain stock level in the warehouse for example instead of having $100 \%$ blocked events, they could have $70 \%$ blocked and $30 \%$ stock events. This would reduce the lead time from 2-3 weeks to a week or less. Although this might increase the inventory cost but it would also increase the customer satisfaction which is our ultimate goal. 
- Moreover, provide more training for the employees using the system especially the customer service team and provide online directory for corporate experts in well defined knowledge domains to enable employees to easily find the appropriate expert in the company.

- Lastly, customize marketing, merchandising and targeting as per country in order to conform to their culture, dialect and tradition.

\section{Acknowledgement}

This research was conducted and published during a sabbatical year from my work as a Professor of MIS at the University of Jordan during the year 2014/2015.

\section{References}

Bhatti T.R. (2005). Critical Success Factors for theImplementation of Enterprise Resource Planning (ERP):Empirical Validation, the second International Conference on Innovation in Information Technology, Zayed University,College of Business, Dubai, UAE.

Brand, H. (1999) SAP R/3 Implementation with ASAP: The Official SAP Guide. Bk\&Cd Rom edition.

Griffith, T.L, Zammuto, R.F.\& Aiman-Smith, L. (1999). Why new technologies fail?, Industrial Management, May-June 1999,.29-34.

Kaplan, R. S., \& Norton, D. P. (1992) The Balanced Scorecard - Measures that Drive Performance, Harvard Business Review 69 (1): 71-79.

Kaplan, Robert S. (2010). Conceptual Foundations of the Balanced Scorecard. HBS. http://dx.doi.org/10.2139/ssrn. 1562586

Laudon, K., \& Laudon, J. (2014). Management Information Systems, $13^{\text {th }}$ Edition, Pearson

Markus, M.L., Axline, S., Petrie, D., Tanis, C. (2000).Learning from adopters' experiences with ERP: Problems encountered and success achieved. Journal of Information Technology, 15, 245-265. http://dx.doi.org/10.1080/02683960010008944

Martin, M.H. (1998). An ERP Strategy. Fortune, 2 February: 95-97.

NETSUITE. (http://www.netsuite.com/portal/resource/articles/erp/what-is-erp.shtml: accessed on 31/10/2015).

Rosemann, Michael, Rosemann, \& Jens, Wiese. (2015). Measuring the Performance of ERP Software - a Balanced Scorecard Approach, Proc. 10th Australasian Conference on Information Systems, 1999, Accessed on 31/10 at http://citeseerx.ist.psu.edu/viewdoc/download?doi=10.1.1.4.9176\&rep=rep1\&type=pdf

Uwizeyemungu, Sylvestre, \& Louis Raymond. (2013). Essential Characteristics of an ERP System: Conceptualization and Operationalization. Hrcak.srce.hr/file/116377, 27 Oct. 2005. Web. 29 Dec. 2013. 


\section{Macrothink}

Journal of Management Research ISSN 1941-899X 2016, Vol. 8, No. 1

Wallace, Thomas F., \& Michael H. Kremzar. (2002). ERP: making it happen: the implementers' guide to success with enterprise resource planning, 14 . Wiley. com.

Zhu, C.Y., \& Ma, G.H. (1999). New Horizon of Management-ERP and Supply Chain Management. China Electronics Audio and Video Press, Beijing.

\section{Copyright Disclaimer}

Copyright for this article is retained by the author(s), with first publication rights granted to the journal.

This is an open-access article distributed under the terms and conditions of the Creative Commons Attribution license (http://creativecommons.org/licenses/by/3.0/). 